\title{
Evaluation of the Frequency of Occupational Hazards Among a Group of Iranian General Dentists and its Prevention Criteria
}

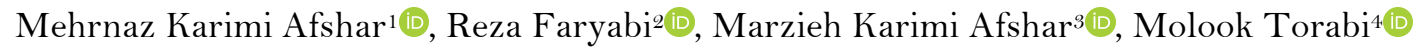

\begin{abstract}
'Department of Prosthodontics, School of Dentistry, Shiraz University of Medical Sciences, Shiraz, Iran.
${ }^{2}$ School of Dentistry, Kerman University of Medical Sciences, Kerman, Iran.

${ }^{3}$ Department of Orthodontics, School of Dentistry, Kerman University of Medical Sciences, Kerman, Iran.

${ }^{4}$ Kerman Social Determinants of Oral Health Research Center, School of Dentistry, Kerman University of Medical Sciences, Kerman, Iran.
\end{abstract}

Correspondence: Marzieh Karimi Afshar, Orthodontics Department, School of Dentistry, Kerman University of Medical Sciences, Shafa Ave, Jomhoori Islami BLVD, Kerman 7618759689, Iran. E-mail: marzieh.k.afshar@gmail.com

Academic Editor: Catarina Ribeiro Barros de Alencar

Received: 14 April 2021 / Review: 19 July 2021 / Accepted: 26 July 2021

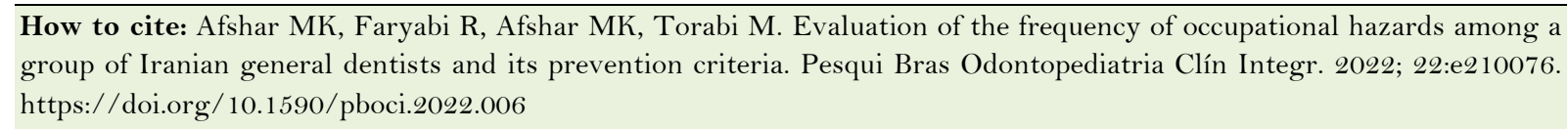

\begin{abstract}
Objective: To evaluate the frequency of occupational hazards and the criteria for their prevention among Iranian dentists. Material and Methods: This cross-sectional study was conducted on 187 general dentists in Kerman. The data collection tool was a questionnaire including personal information (gender, age, marital status, condition and place and years of employment, and the average of weekly working hours) and a valid and reliable questionnaire of occupational hazards, including 24 questions about occupational hazards (6 domain) and nine questions about criteria for the prevention of the risks of dentistry. The t-test, chi-square, and linear regression were used. Results: $92(49.2 \%)$ were men. The mean and standard deviation of the score of occupational hazards was $27.04 \pm 16.21$ out of 96 , and the criteria of prevention were $22.00 \pm 7.28$ out of 36 . Regression analysis showed significant correlations between single statuses, years of occupational and type of employment, weekly work hours and occupational hazards, participation in occupational injury identification courses, and hepatitis vaccination. In addition, there were significant correlations between gender, age, weekly work hours, and preventive measures. Moreover, $3.2 \%$ of dentists were in a high-risk group and $26.2 \%$ were weak in preventive measures. Conclusion: A total of $32.6 \%$ of dentists are at moderate risk of occupational hazards, and $10.7 \%$ meet the prevention criteria properly. It is recommended to hold training classes to identify occupational hazards and the criteria for their prevention among dentists.
\end{abstract}

Keywords: Occupational Diseases; Occupational Dentistry; Occupational Health; Health Status. 


\section{Introduction}

Occupational hazards are the risk and the danger as the consequences of the job nature or a particular job with a history dating back to the 18th century. When Bernardino Ramazzin, the father of occupational medicine, defined the role of occupation in the dynamics of disease and health [1,2], occupational hazards refer to the obvious and perceived threats posing great psychological pressure on the individuals in the workplace and gradually reduce the level of well-being and health of the individual [3].

The National Institute for Occupational Safety and Health sees occupational hazards like physical, chemical, biological, and psychological threats taking place when occupational needs are incompatible with the abilities, resources, or needs of employees [4]. In addition, work accidents leave significant negative effects on the production and economy of countries [5].

Dentistry is considered a high-risk job by those active in this field and the community [6,7]. Studies have shown that dentists have worse and more common health problems than other high-risk professions in the medical group [8].

Dentists' occupational hazards can be divided into infection transmission risks, psychological, allergic reactions, and physical hazards, hazards caused by mercury, ionizing and non-ionizing radiation, and anesthetic gases [9-18]. In addition, dentists are in danger of hearing loss because of the sound [19] and at risk of eye fatigue and pain because of working in low-light environments [20].

Needle heads and other sharp instruments, aerosols, and secretions can lead to transmission of lifethreatening viral infections like HIV, hepatitis C, and hepatitis B [21]. The interaction with patients, physical stress and economic pressures among dentists have been shown to negatively affect the mental health of dental professionals [8]. The prevalence of carpal tunnel syndrome is higher in people working in the dental profession [22]. Fatigue and back pain were the most prevalent physical complaints in the study of occupational hazards in Latvian dentists [23].

Considering the involvement of general scarcity of information in this regard, especially in the dental field in Iran, and in continuing our interest in medical research [24-27] and most of the published articles on occupational hazards are in nurses and articles related to occupational hazards in dentists are based on skeletal problems and burnout. Therefore, as there are no studies on occupational hazards of dentists in Kerman covering most of occupational hazards and evaluating the awareness of occupational hazards can help identify the most common problems of dentists, this study was conducted to examine the frequency of occupational hazards in general dentists in Kerman (South East of Iran).

\section{Material and Methods}

Study Design and Sample

This descriptive-analytical cross-sectional study was carried out on general dentists in Kerman, Iran. The sample volume was determined as 163 people using the sample size formula $n=\left(\mathrm{z}^{2 *} \mathrm{p}[1-\mathrm{p}]\right) / \mathrm{d}^{2}$ with a significance level of 0.01 , study power $95 \%$, and a confidence interval of 0.04 . Considering the possible drop in sample volume, 200 general dentists working in Kerman were selected based on a simple sampling method to reach the sample size. The inclusion criteria were a history of occupational therapy over 12 months and no history of chronic mental and skeletal disease. The exclusion criteria were unwillingness to cooperate or complete the questionnaire. 
The data collection tool was a questionnaire, with two personal information sections (gender, age, marital status, years of employment, average weekly working hours, participation in occupational injury identification courses, and hepatitis vaccination). The second section of the questionnaire had 24 questions about occupational hazards, including three questions about physical hazards, three questions about dealing with legal problems, three questions about psychological hazards, three questions about biological hazards, and three questions about chemical hazards. Moreover, nine questions on dental risk prevention criteria, including performing light sports movements, using masks, using guns, using glasses for light cures, and handwashing, were discussed too. The questionnaire was scored on a Likert scale with 5 to very high scores. "At all” received a score of zero and "very high" four.

Thus, the Occupational Risk Questionnaire's total score range was zero to 96, and the range of occupational risk prevention scores from zero and 36. The questionnaire was made based on the papers and texts by the researcher and was approved with a total validity coefficient of 0.87 and a reliability coefficient of 0.81 .

\section{Data Analysis}

After collecting data, they were analyzed using IBM SPSS Statistics software version 21.0 (IBM Corp., Armonk, NY, USA). The t-test, chi-square and linear regression were used. The significance level was set at 0.05 .

\section{Ethical Clearance}

The study was approved by the ethics committee of Kerman University of Medical Sciences with the code IR.KMU.AC.1397.436.\#97000758.

\section{Results}

Of the 187 participants, $50.8 \%$ were females. A total of $40.6 \%$ were in 29 -33-year age group, and $52.4 \%$ were married. Forty-three participants worked 24-28 hours a week, 55 people (29.4\%) worked for 5-8 years, 83 people $(44.4 \%)$ were contract workers. Moreover, $51.9 \%$ were employed in the clinics and $97.3 \%$ were vaccinated against hepatitis B. Additionally, $77.5 \%$ were willing to participate in occupational hazards courses (Table 1).

Table 1. Distribution of participants according to demographic characteristics.

\begin{tabular}{|c|c|c|}
\hline Variables & $\mathbf{N}$ & $\%$ \\
\hline \multicolumn{3}{|l|}{ Gender } \\
\hline Male & 92 & 49.2 \\
\hline Female & 95 & 50.8 \\
\hline \multicolumn{3}{|l|}{ Age } \\
\hline $24-28$ & 35 & 18.7 \\
\hline 29-33 & 76 & 40.6 \\
\hline $34-38$ & 34 & 18.2 \\
\hline $39-43$ & 11 & 5.9 \\
\hline $44-48$ & 6 & 3.2 \\
\hline $49-53$ & 12 & 6.4 \\
\hline $54-58$ & 6 & 3.2 \\
\hline 59 and above & 7 & 3.8 \\
\hline \multicolumn{3}{|l|}{ Marriage Status } \\
\hline Married & 98 & 52.4 \\
\hline Single & 89 & 47.6 \\
\hline
\end{tabular}




\begin{tabular}{lcc} 
Occupational Status & & 33.2 \\
Government Recruitment & 62 & 44.4 \\
Contractual & 83 & 15.0 \\
Perform Accrual Services & 28 & 7.5 \\
Family Dentist & 14 & 20.9 \\
Place of Employment & 39 & 51.9 \\
$\quad$ Office & 97 & 27.3 \\
Clinic & 51 & 97.9 \\
Office + Clinic & 188 & 2.1 \\
Hepatitis B Vaccination & 4 & 77.5 \\
Yes & & 22.5 \\
No & 145 & 42 \\
Interest in participating in occupational hazard training workshops & \\
Yes & & 2 \\
No & & 2 \\
\hline
\end{tabular}

Concerning responding to the prevention criteria questions, the most common task was to use a special box to dispose of sharp objects and needles. The lowest criteria was to perform light sports movements between patients' work (Table 2 ).

Table 2. Mean and standard deviation of the occupational hazards domains.

\begin{tabular}{|c|c|c|c|c|c|}
\hline Variables & Mean & Standard Deviation & Median & Minimum & Maximum \\
\hline Muscular-Skeletal Hazards & 9.97 & 4.44 & 9.00 & $\mathrm{O}$ & 22 \\
\hline Chemical Hazards & 2.44 & 2.21 & 1.00 & $\mathrm{O}$ & 12 \\
\hline Legal Hazards & 1.77 & 1.70 & 1.00 & $\mathrm{O}$ & 10 \\
\hline Biological Hazards & 3.27 & 2.67 & 3.00 & $\mathrm{O}$ & 13 \\
\hline Physical Hazards & 3.48 & 2.54 & 3.00 & $\mathrm{O}$ & 12 \\
\hline Psychological Hazards & 7.39 & 4.80 & 7.00 & $\mathrm{O}$ & 22 \\
\hline Occupational Hazards [Total] & 27.04 & 16.21 & 25.00 & $\mathrm{O}$ & 85 \\
\hline Preventive Measures & 21.55 & 7.28 & 22.00 & O & 36 \\
\hline
\end{tabular}

Tables 3 and 4 show the relationship between gender and marital status with each area of occupational hazards. In all areas and the whole questionnaire except legal (marginal) risks, the women were significantly more exposed. However, in the field of prevention, they had higher scores and outperformed. In all domains and overall, married people were significantly more exposed, had higher scores, and performed in prevention.

Table 3. The relationship between gender and score of occupational hazards and prevention criteria.

\begin{tabular}{|c|c|c|c|c|}
\hline Domains of Occupational Hazards & Gender & Mean & Standard Deviation & p-value \\
\hline \multirow[t]{2}{*}{ Muscular-Skeletal Hazards } & Male & 7.40 & 4.25 & 0.0001 \\
\hline & Female & 10.50 & 4.09 & \\
\hline \multirow[t]{2}{*}{ Chemical Hazards } & Male & 1.93 & 1.38 & 0.0001 \\
\hline & Female & 3.02 & 2.62 & \\
\hline \multirow[t]{2}{*}{ Legal Hazards } & Male & 1.59 & 1.46 & 0.071 \\
\hline & Female & 1.93 & 1.91 & \\
\hline \multirow[t]{2}{*}{ Biological Hazards } & Male & 2.66 & 2.50 & 0.002 \\
\hline & Female & 3.87 & 2.71 & \\
\hline \multirow[t]{2}{*}{ Physical Hazards } & Male & 2.53 & 2.10 & 0.001 \\
\hline & Female & 4.40 & 2.60 & \\
\hline \multirow[t]{2}{*}{ Psychological Hazards } & Male & 5.38 & 3.85 & 0.001 \\
\hline & Female & 9.33 & 4.85 & \\
\hline \multirow[t]{2}{*}{ Occupational Hazards [Total $]$} & Male & 15.44 & 10.05 & 0.001 \\
\hline & Female & 23.73 & 12.19 & \\
\hline \multirow[t]{2}{*}{ Preventive Measures } & Male & 18.01 & 6.97 & 0.001 \\
\hline & Female & 24.97 & 5.80 & \\
\hline
\end{tabular}


Table 4. The relationship between marital status and occupational hazard scores and prevention criteria.

\begin{tabular}{|c|c|c|c|c|}
\hline Domains of Occupational Hazards & Marital Status & Mean & Standard Deviation & p-value \\
\hline \multirow{2}{*}{ Muscular-Skeletal Hazards } & Single & 7.28 & 4.08 & 0.001 \\
\hline & Married & 10.52 & 4.20 & \\
\hline \multirow[t]{2}{*}{ Chemical Hazards } & Single & 1.89 & 1.38 & 0.001 \\
\hline & Married & 2.96 & 2.56 & \\
\hline \multirow[t]{2}{*}{ Legal Hazards } & Single & 1.35 & 1.15 & 0.001 \\
\hline & Married & 2.20 & 1.96 & \\
\hline \multirow[t]{2}{*}{ Biological Hazards } & Single & 2.52 & 2.35 & 0.001 \\
\hline & Married & 3.95 & 2.74 & \\
\hline \multirow[t]{2}{*}{ Physical Hazards } & Single & 2.75 & 2.30 & 0.001 \\
\hline & Married & 4.14 & 2.58 & \\
\hline \multirow[t]{2}{*}{ Psychological Hazards } & Single & 9.16 & 4.62 & 0.001 \\
\hline & Married & 9.33 & 4.85 & \\
\hline \multirow[t]{2}{*}{ Occupational Hazards [Total] } & Single & 15.10 & 9.85 & 0.001 \\
\hline & Married & 23.79 & 12.14 & \\
\hline \multirow[t]{2}{*}{ Preventive Measurements } & Single & 17.73 & 6.71 & 0.001 \\
\hline & Married & 25.02 & 5.93 & \\
\hline
\end{tabular}

Multivariate analysis by linear regression method showed that the increase in working hours, increase in biological risk, mental and psychological domain significantly increase musculoskeletal risk. The increase in mental and psychological domain score, being single, increasing years of employment, not getting vaccinated, and job type and increase in working hours per week significantly increase the overall risks (Table 5).

Table 5. The relationship between variables with overall risk and risk prevention.

\begin{tabular}{llccc}
\hline & Variables & B & t & p-value \\
\hline Total Hazards & Marriage Status & -2.727 & -3.001 & 0.003 \\
& Occupational Years & 1.398 & 5.398 & $>0.001$ \\
& Occupational Status & 1.510 & 3.435 & 0.001 \\
& Vaccination & -9.024 & -3.607 & $>0.001$ \\
\multirow{3}{*}{ Prevention } & Weekly Work Hours & 1.434 & 4.919 & $>0.001$ \\
& Gender & 4.621 & 6.561 & $>0.001$ \\
& Age & 1.164 & 5.505 & $>0.001$ \\
& Weekly Work Hours & 1.285 & 5.058 & $>0.001$ \\
\hline
\end{tabular}

Figure 1 shows the severity of occupational hazards and prevention criteria. As seen, 3.2\% were at high occupational risk, and $26.2 \%$ were weak in compliance with prevention criteria.

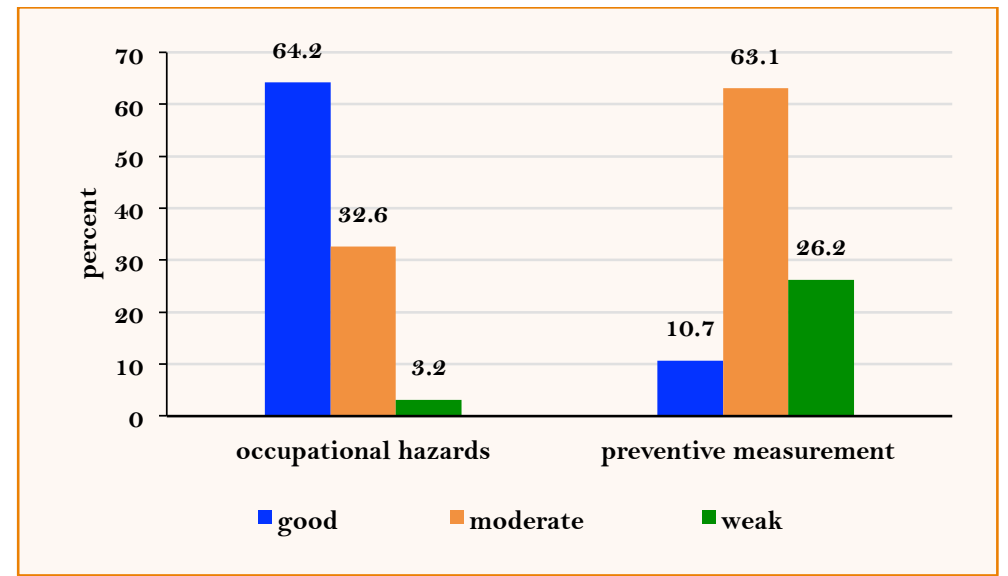

Figure 1. Frequency distribution of the individuals according to the occupational hazards and prevention criteria. 
Figures 2 and 3 are the frequency distribution of severity of occupational hazards and prevention criteria in terms of gender.

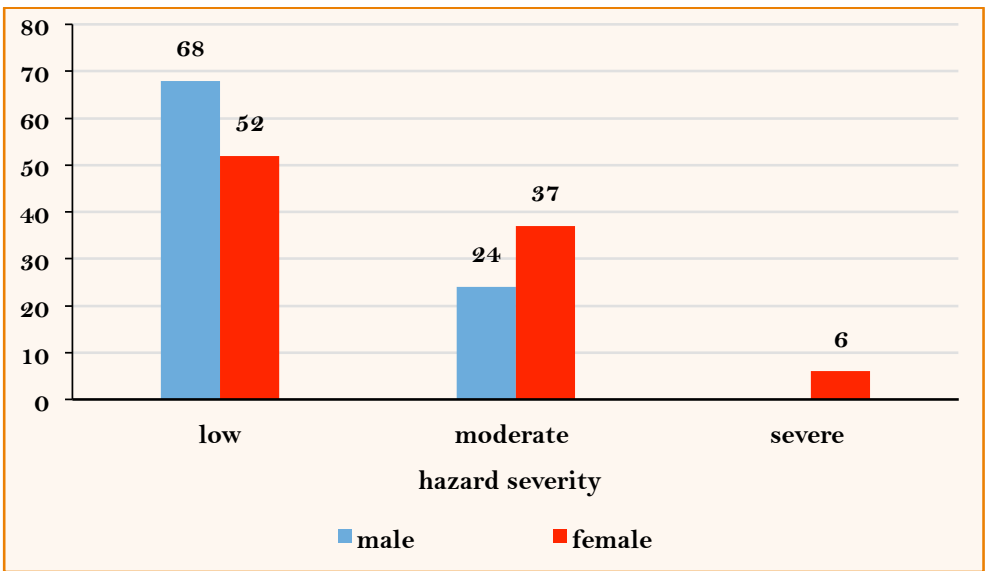

Figure 2. Frequency distribution of the individuals according to the occupational hazards by gender.

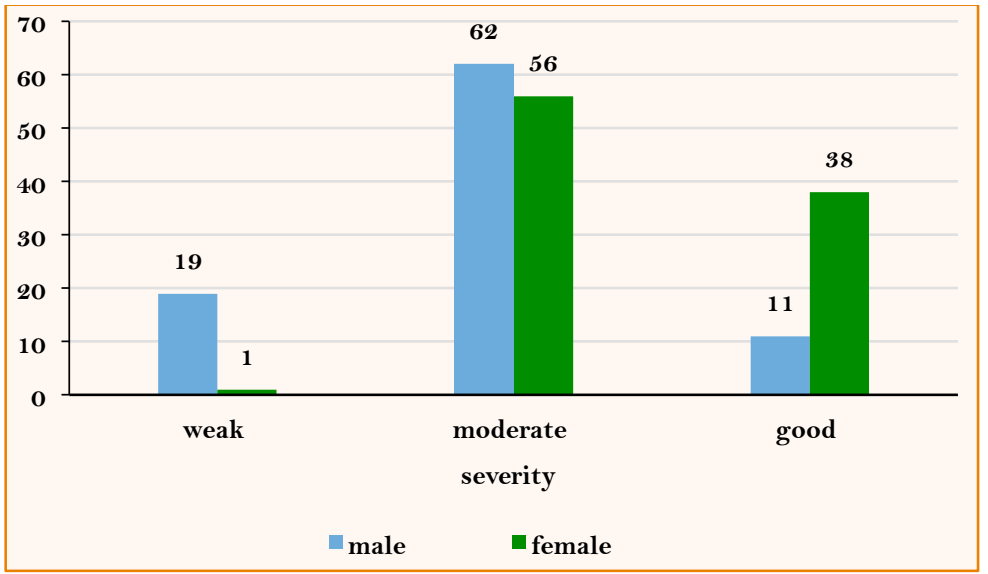

Figure 3. Frequency distribution of individuals according to the gender-based prevention criteria.

According to the chi-square test, there was a statistically significant difference between the genders of individuals with occupational hazards $(\mathrm{p}=0.003)$. Moreover, there was a statistically significant difference between the prevention criteria and gender. The women observed more $(p=0.001)$.

\section{Discussion}

Dentistry is seen as a high-risk job by dentists and people in the community [6,7]. It has been shown that dentists have worse and more common health problems than other high-risk professions in the medical group [8].

In this study, $32.6 \%$ of the dentists were exposed to moderate risk, and $3.2 \%$ were at high occupational risk. It seems that people have to be aware of job hazards. Occupational risk prevention criteria were poor in 26.2\%. As performing preventive measures can prevent the development of musculoskeletal disorders in the dentist's health against the transmission of microbial and viral infections to the dentist and the patient, it seems essential to train and control the prevention criteria. 
Women were significantly at higher risk. The physical condition and more responsibilities of the women in the family and in front of their children can lead to this. Therefore, serious attention to the occupational health of dentists, especially women, seems necessary. In the present study about the occupational risk in all areas and the whole questionnaire, a statistically significant difference was observed between demographic variables and gender. Women had significantly higher scores. This may be because of the physiological and physical condition of women. Moreover, besides dental work, they are active in household chores too. Furthermore, in all areas and the total score, married dentists were significantly more at risk of occupational hazards than single dentists.

In the present study, $96.3 \%$ of the individuals reported a range of low to very high levels of musculoskeletal pain in the past year. The lowest prevalence of pain was in the wrist (17.1\% at all). Neck pain was observed in $82.9 \%$ and shoulder in $89.3 \%$. These results can be compared to the study [3] in Lithuania, where $86.5 \%$ of the dentists had general musculoskeletal problems. A systematic review of the dentists' occupational problems [28] showed that musculoskeletal disorders were the commonest occupational health problem among dentists. There was a statistically significant difference between the area of musculoskeletal disorders and gender in the present study. Female dentists had a higher mean score.

Different studies have reported on the difference between men and women. For example, in a study among postgraduate students and faculty members of the School of Dentistry of the University of Barcelona [29], women were significantly more likely to have musculoskeletal complaints than men. Furthermore, in Saudi Arabia [20], there was a significant difference between male and female dentists regarding musculoskeletal pain in line with our study.

In the present study, $69.0 \%$ of the participants had some degree of needle stick and $57.2 \%$ skin injuries caused by milling, razor blades, etc. The prevalence of needle sticks reported in Brazil was 19.2\% [30], 61.7\% in Germany [31], and 57.75\% in Croatia [32]. Moreover, $66.7 \%$ of dentists had skin injuries in another study by Shah et al. [33] in Washington.

In a study of Shiraz students, $80 \%$ of the students were exposed to the patient's saliva and blood [34]. In addition, half of the students and Indian faculty members were injured by sharp objects in the treatment of patients [1]. In dentistry, percutaneous skin injuries like needle sticks and sharp object injuries are widely seen. The reason for this exposure is that dentists are working in an area with limited access, low vision, and frequent use of sharp tools.

In the present study, $59.4 \%$ of the dentists had eye problems because of foreign objects in their eyes. In the study in South-Western Saudi Arabia [35], 29.6\% and 51.1\% of dentists had ocular accidents, respectively, because of foreign bodies and fluid secretion, and in the study among Greek endodontists, 73\% had ocular injuries [36]. Eye injuries in dentistry may be from disposable materials like scale during scaling or droplets of body fluids (bacteria and aerosols) while using high-speed handpieces [37].

In the current study, $70.6 \%$ of the people were exposed to radiation. It was revealed that dental personnel is exposed to ionizing and non-ionizing radiation [8]. Having a radiograph and conducting radiography in dental offices makes the dentist prone to ionizing radiation. Non-ionizing radiation damage that occurs with the use of composites and other resins, and lasers in dental treatments, is another source of damage to the eye and other tissues [6].

Blue light is used increasingly for beauty treatments, becoming more common. However, light can cause different toxicities and heat damage by light has to be taken into account. In recent years, eye damage and non-thermal damage by blue light, called blue light hazard, have been considered [38]. 
In the current study, only $16 \%$ claimed not to have noise in the workplace. Dentists are exposed to varying degrees of noise in clinics and laboratories. The noise level in the dental environment is below 85 decibels. Higher than this, the risk of hearing loss is negligible [39]. In this study, $54.5 \%$ of the subjects had no allergies to dental materials. Professional activity-related allergies were reported in Romanian dentists at $76.1 \%[40]$.

A total of $27.3 \%$ of the participants had a lot of mental fatigue because of the dental work. $30.46 \%$ of the dentists in Iran suffered from severe emotional fatigue [41]. Studies have revealed that occupational stress among dentists is more than in other jobs [42,43]. Concerning the criteria for preventing occupational hazards, the most prevalent prevention was using a mask and throwing away the needles and sharp objects in a safety box. In the study in Nigeria [2], the lowest prevention criterion was using goggles. $100 \%$ of dentists in Mumbai wore masks, gloves, and goggles while working on a patient [44]. Additionally, 25\% reported never exercising at least three times a week. It was shown that the incidence of musculoskeletal disorders decreases with regular exercise [45].

In the present study, $97.7 \%$ of the participants said they had been vaccinated against the hepatitis B virus. In India [46] 88.4\%, in Nigeria [45] 68.4\% and in Saudi Arabia 74\% [20] were vaccinated. The reason for the high percentage of vaccinations in our study may be that dentists are more aware of the risks of infection with the hepatitis virus and have thus been vaccinated against it.

Women were significantly better and more prevented in terms of heeding prevention criteria. This may be in the obsession of more women. The years of employment increase occupational hazards based on the regression test of increasing working hours.

In this study, contractual dentists and $\mathrm{k}$ coefficient were more at risk of occupational hazards, with this difference being significant. Perhaps this difference is that contracted people and $k$ coefficient within the scope of the regulations set and with the tools and materials in the purchase and selection may not have a role and pose a greater risk.

\section{Conclusion}

A high prevalence of musculoskeletal disorders was observed. There was a statistically significant relationship between gender and marital status and an increase in years of work with occupational hazards. The most common task in terms of prevention was to use a safety box to dispose of sharp objects and needles, and the lowest criteria was to perform light sports movements between patients' work. Holding special workshops to identify occupational hazards and prevention criteria is recommended.

\section{Authors' Contributions}

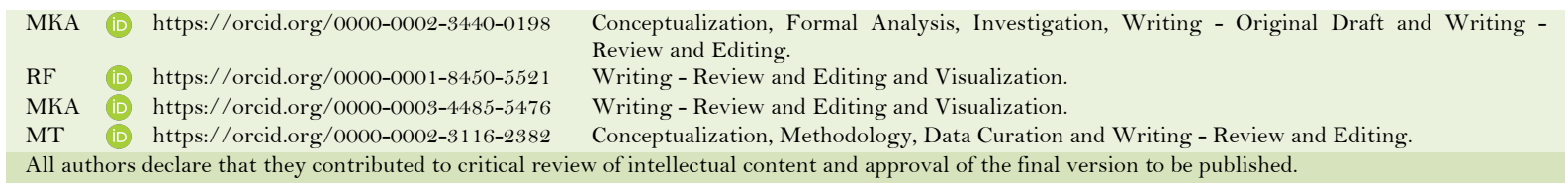

\section{Financial Support}

None.

\section{Conflict of Interest}

The authors declare no conflicts of interest. 


\section{Data Availability}

The data used to support the findings of this study can be made available upon request to the corresponding author.

\section{References}

[1] Tadakamadla J, Kumar S, Swapna LA, Reddy S. Occupational hazards and preventive practices among students and faculty at a private dental institution in India. Stomatologija 2012; 14(1):28-32.

[2] Fasunloro A, Owotade FJ. Occupational hazards among clinical dental staff. J Contemp Dent Pract 2004; 5(2):134-52.

[3] Lambert EG, Hogan NL, Griffin ML. The impact of distributive and procedural justice on correctional staff job stress, job satisfaction, and organizational commitment. J Crim Justice 2007; 35(6):644-56. https://doi.org/10.1016/j.jcrimjus.2007.09.001

[4] Centers for Disease Control and Prevention. The National Institute for Occupational Safety and Health. Exposure to Stress: Occuptional Hazards in Hospitals. DHHS (NIOSH) Publication No. 2008-136; 2008.

[5] Nekooi Moghadam M, Amiresmaili MR, Mirshahi F, Sefidbor N, Sharifi T, Ghorbani R, et al. The rate of occupational hazards and its effective factors in nurses of non-educational hospital of Sirjan and Baft in 2011 . J. Health Dev 2013; 2(3):235-49.

[6] Ayatollah A, Ayatollahi F, Mellat Ardekani A, Bahrololoomi R, Ayatollahi J, Ayatollahi A, et al. Occupational hazards to dental staff. Dent Res J 2012; 9(1):2-7. https://doi.org/10.4103/1735-3327.92919

[7] Matoš K, Jurec Z, Ivan Galić, Marin Vodanović. Education on occupational health and health related habits among dental students in Croatia. Acta Stomatol Croat 2016; 50(1):49-57. https://doi.org/10.15644/asc50/1/7

[8] Gambhir RS, Singh G, Sharma S, Brar R, Kakar H. Occupational health hazards in current dental profession- a review. Open Occup Health Safety J 2011; 3(1):57-64. https://doi.org/10.2174/1876216601103010057

[9] Ayatollahi J, Bahrololoomi R, Ayatollahi F. Vaccination of dentist and other oral health care providers. J Den Med 2005; $18(3): 5-14$.

[10] Ayatollahi J, Sharifi MR, Sabzi F, Zare AR. Blood level anti-HBS due to HB vaccine in health care personnel of Shahid Sadoughi Hospital-Yazd. Iran J Obstet Gynecol Infertil 2004; 7(1):48-51.

[11] Leggat PA, Kedjarune U. Bacterial aerosols in the dental clinic: a review. Int Dent J 2001; 51(1):39-44. https://doi.org/10.1002/j.1875-595x.2001.tbo0816.x

[12] Samaranayake P. Re-emergence of tuberculosis and its variants: Implications for dentistry. Int Dent J 2002; 52(5):330-6. https://doi.org/10.1002/j.1875-595x.2002.tbo0880.x

[13] Rodríguez Vázquez LM, Rubiños López E, Varela Centelles A, Blanco Otero AI, Varela Otero F, Varela Centelles P. Stress amongst primary dental care patients. Med Oral Patol Oral Cir Bucal 2008; 13(4):E253- E256

[14] Winwood PC, Winefield AH, Lushington K. The role of occupational stress in the maladaptive use of alcohol by dentists: A study of South Australian general dental practitioners. Aust Dent J 2003; 48(2):102-9. https://doi.org/10.1111/j.1834-7819.2003.tboo017.x

[15] Rubel DM, Watchorn RB. Allergic contact dermatitis in dentistry. Aust J Dermatol 2000; $41(2)$ :63-9. https://doi.org/10.1046/j.1440-0960.2000.00398.x

[16] Al-Khatib IA, Darwish R. Assessment of waste amalgam management in dental clinics in Ramallah and Al-Bireh cities in Palestine. Int J Environ Health Res 2004; https://doi.org/10.1080/09603120420002000218598

[17] Shuhaiber S, Einarson A, Radde IC, Sarkar M, Koren G. A prospective controlled study of pregnant veterinary staff exposed to inhaled anesthetics and X-rays. Int J Occup Med Environ Health 2002; 15(4):363-73.

[18] Henderson KA, Matthews IP. Environmental monitoring of nitrous oxide during dental anaesthesia. Br Dent J 2000; 188(11):617-9. https://doi.org/10.1038/sj.bdj.4800556

[19] Garner GG, Federman J, Johnson A. Noise induced hearing loss in the dental environment: An audiologist's perspective. J Georgia Dent Assoc 2002; 17-19.

[20] Al-aslami RA, Elshamy FMM, Maamar EM, Shannaq AY, Dallak AE, Alroduni AA. Knowledge and awareness towards occupational hazards and preventive measures among students and dentists in Jazan Dental College, Saudi Arabia. Open Access Maced J Med Sci 2018; 6(9):1722-6. https://doi.org/10.3889/oamjms.2018.345

[21] Shah SM, Merchant AT, Dosman JA. Percutaneous injuries among dental professionals in Washington State. BMC Public Health 2006; 6:269. https://doi.org/10.1186/1471-2458-6-269

[22] Abichandani S, Shaikh S, Nadiger R. Carpal tunnel syndrome - an occupational hazard facing dentistry. Int Dent J 2013; 63(5):230-6. https://doi.org/10.1111/idj.12037

[23] Puriene A, Aleksejuniene J, Petrauskiene J, Balciuniene I, Janulyte V. Self-reported occupational health issues among Lithuanian dentists. Ind Health 2008; 46(4):369-74. https://doi.org/10.2486/indhealth.46.369

[24] Afshar MK, Torabi M, Bahremand M, Afshar MK, Najmi F, Mohammadzadeh I. Oral health literacy and related factors among pregnant women referring to Health Government Institute in Kerman, Iran. Pesqui Bras Odontopediatria Clín Integr 2020; 20:e5337. https://doi.org/10.1590/pboci.2020.011 
[25] Torabi M, Shahravan A, Afshar MK, Shenasa Y, Mobasher M. Knowledge and attitude about research ethics among Iranian dental students. Pesqui Bras Odontopediatria Clín Integr 2021; 21:e0127. https://doi.org/10.1590/pboci.2021.081

[26] Afshar MK, Safarian F, Torabi M, Farsinejad A, Mohammadzadeh I. Comparison of TNF- $\alpha$ and IL-1 $\beta$ concentrations in gingival crevicular fluid during early alignment stage of orthodontic treatment in adults and adolescents. Pesqui Bras Odontopediatria Clín Integr 2020; 20:e0004. https://doi.org/10.1590/pboci.2020.086

[27] Zihayat B, Khodadadi A, Torabi M, Mehdipour M, Basiri M, Asadi-Shekarri M. Wound healing activity of sheep's bladder extracellular matrix in diabetic rats. Biomed Eng-Appl Basis Commun 2018; 30(2):1850015. https://doi.org/10.4015/S1016237218500151

[28] Moodley R, Naidoo S, Wyk JV. The prevalence of occupational health-related problems in dentistry: A review of the literature. J Occup Health 2018; 60(2):111-25. https://doi.org/10.1539/joh.17-0188-RA

[29] Harutunian K, Gargallo-Albiol J, Figueiredo R, Gay-Escoda C, et al. Ergonomics and musculoskeletal pain among postgraduate students and faculty members of the School of Dentistry of the University of Barcelona (Spain). A crosssectional study. Med Oral Patol Oral Cir Bucal 2011; 16(3):425-9. https://doi.org/10.4317/medoral.16.e425

[30] Martins A M, Santos NC, Lima MD, Pereira RD, Ferreira RC. Needle stick and sharp instrument injuries among dentists in Montes Claros, Brazil. Arq Odontol 2010; 46(3):127-35. https://doi.org/10.4103/ccd.ccd_1173_16

[31] Wicker S, Rabenau HF. Occupational exposures to bloodborne viruses among German dental professionals and students in a clinical setting. Int Arch Occup Environ Health 2010; 83(1):77-83. https://doi.org/10.1007/s00420-009-0452-3

[32] Pavičin IS, Lovrić Z, Çeshko AZ, Vodanović M. Occupational injuries among dentists in Croatia. Acta Stomatol Croat 2020; 54(1):51-9. https://doi.org/10.15644/asc54/1/6

[33] Shah SM, Merchant AT, Dosman JA. Percutaneous injuries among dental professionals in Washington State. BMC Public Health 2006; 6:269. https://doi.org/10.1186/1471-2458-6-269

[34] Shaghaghian S, Golkari A, Pardis S, Rezayi A. Occupational exposure of Shiraz dental students to patients' blood and body fluid. J Dent 2015; 16(3):206-13.

[35] Alsabaani NA, Awadalla NJ, Abu Saq IH, Abualiat ZM, Alshahrani MA, Alqahtani AM, et al. Occupational ocular incidents in dentists: a multicentre study in southwestern Saudi Arabia. Int Dent J 2017; 67(6):371-7. https://doi.org/10.1111/idj.12324

[36] Zarra T, Lambrianidis T. Musculoskeletal disorders amongst Greek endodontists: a national questionnaire survey. Int Endod J 2014; 47(8):791-801. https://doi.org/10.1111/iej.12219

[37] Chopra SS, Pandey SS. Occupational hazards among dental surgeons. Med J Armed Forces India 2007; 63(1):23-5. https://doi.org/10.1016/S0377-1237(07)80100-6

[38] Yoshino F, Yoshida A. Effects of blue-light irradiation during dental treatment. Jpn Dent Sci Rev 2018; 54(4):160-8. https://doi.org/10.1016/j.jdsr.2018.06.002

[39] Mohammed NS, Shaik MA. Occupational hazards in modern dentistry. Int J Experiment Dent Sci 2013; 2(1):33-40. https://doi.org/10.5005/jp-journals-10029-1037

[40] Bârlean L, Dănilă I, Săveanu I, Balcoş C. Occupational health problems among dentists in Moldavian Region of Romania. Rev Med Chir Soc Med Nat Iasi 2013; 117(3):784-8.

[41] Torabi Parizi M, Ali Eskandarizadeh A, Karimi Afshar M, Asadi Shekaari M, Jangjoo A. The frequency of job burnout among dentists of Kerman City. J Health Dev 2015; 3(4):333-40.

[42] LaPorta LD. Occupational stress in oral and maxillofacial surgeons: tendencies, traits, and triggers. Oral Maxillofac Surg Clin North Am 2010; 22(4):495-502. https://doi.org/10.1016/j.coms.2010.07.006

[43] Rada RE, Johnson-Leong C. Stress, burnout, anxiety and depression among dentists. J Am Dent Assoc 2004; 135(6):788-94. https://doi.org/10.142 19/jada.archive.2004.0279

[44] Ramaswami E, Nimma V, Jakhete A, Lingam AS, Contractor I, Kadam S. Assessment of occupational hazards among dentists practicing in Mumbai. J Family Med Prim Care 2020; 9(4): 2016-21. https://doi.org/10.4103/jfmpc.jfmpc_1180_19

[45] Sharma P, Golchha V. Awareness among Indian dentist regarding the role of physical activity in prevention of work related musculoskeletal disorder. Indian J Dent Res 2011; 22(3):381-4. https://doi.org/10.4103/0970-9290.87057

[46] Mehta A, Gupta M, Upadhyaya N. Status of occupational hazards and their prevention among dental professionals in Chandigarh, India: a comprehensive questionnaire survey. Dent Res J 2013; 10(4):446-51. 